\title{
PROBLEM BIROKRASI DALAM MENINGKATAN PELAYANAN PUBLIK PADA SEKRETARIAT DAERAH KABUPATEN MUNA
}

\author{
Oleh: \\ La Ode Muhammad Elwan ${ }^{1}$ \\ ${ }^{1}$ Dosen Fakultas Ilmu Sosial dan Ilmu Politik Universitas Halu Oleo \\ muh.elwan@uho.ac.id
}

\begin{abstract}
The purpose of this study is to find out knowing the problem (inhibiting factors) of bureaucracy in improving the quality of public services at the Muna Regency Regional Secretariat.

This study uses a type of qualitative research with descriptive analysis methods in order to describe the problem (inhibiting factors) of bureaucracy in improving the Quality of Public Services at the Muna Regency Regional Secretariat by using data collection methods through interviewing informants and observations.

The conclusion of this study is that the problem (inhibiting factors) of bureaucracy in order to improve the quality of public services, namely, human resources that carry out service tasks are not optimal. Because most of those who served in the ministry had a high school education background (high school) which was as many as 19 people or 31.67 percent. Then the supporting facilities owned by the Muna Regency Secretariat have met service needs, but their utilization is relatively not optimal, this is possible because of limited human resources that have not been able to utilize the facility optimally.
\end{abstract}

\section{Keywords : Problem of Bureaucracy, Quality, Public Service}

\section{PENDAHULUAN}

Birokrasi yang memiliki kinerja buruk dalam memberikan pelayanan kepada publik akan sangat mempengaruhi kinerja pemerintah dan masyarakat secara keseluruhan, Dwiyanto (2006:54). Kinerja banyak dipahami oleh kalangan birokrat hanya dari aspek responsibilitas, yakni sejauh mana pelayanan yang diberikan telah sesuai dengan aturan formal yang diterapkan.

Perspektif yang digunakan oleh birokrasi sebagai pemberi layanan merupakan perspektif yang sebenarnya berasal dari pendekatan birokrasi yang cenderung menempatkan diri sebagai regulator daripada sebagai pelayan.

Salusu (2006:8), mengemukakan bahwa "Fungsi utama dari pemerintah ialah mengatur, memerintah, menyediakan fasilitas, serta memberi pelayanan kepada masyarakat. Dalam kehidupan bernegara, berbangsa dan bermasyarakat, kehadiran pemerintahan mutlak diperlukan untuk menegakkan keteraturan masyarakat atau sekelompok manusia yang sebelumnya tidak teratur. Jadi pembentukan pemerintahan adalah untuk memberikan rasa aman, keadilan dan menciptakan keteraturan. Hal ini sebagaimana menurut Mac Iver dalam Hasyim, (1985:35) bahwa:

Untuk menciptakan suasana tertib dan mendukung untuk memenuhi kebutuhan hidupnya, maka dibutuhkan pemerintahan, yaitu organisasi yang dipusatkan untuk mempertahankan suatu sistem ketertiban atas suatu masyarakat, didalamnya terdapat aturan-aturan yang sangat diperlukan karena tidak ada masyarakat dapat berdiri tanpa kontrol atas tindakan-tindakan dorongan alami manusia. 
Pemberian pelayanan publik oleh aparatur pemerintah kepada masyarakat (publik) merupakan perwujudan dan fungsi aparatur negara sebagai pelayan masyarakat (abdi), disamping sebagai abdi negara. Dalam konteks ini masyarakatlah sebagai aktor utama (pelaku) pembangunan, sedangkan pemerintah berkewajiban untuk mengarahkan, membimbing serta menciptakan suasana yang menunjang kegiatan-kegiatan dari masyarakat tersebut. Pada kondisi ini aparatur negara dituntut untuk lebih mampu memperbaiki kinerjanya (pelayanan prima) dan diharapkan lebih mampu merumuskan konsep atau menciptakan iklim yang kondusif, sehingga sumber daya pembangunan dapat menjadi pendorong percepatan terwujudnya masyarakat yang mandiri dan sejahtera. Pelayanan yang telah menunjuk kepada aturan formal dianggap telah memenuhi sendi-sendi pelayanan yang baik dan aparat pelayanan dianggap telah konsisten dalam menerapkan aturan hukum pelayanan, Dwiyanto (2006:56).

Kita semua menyadari pelayanan publik selama ini bagaikan rimba raya bagi banyak orang. Amat sulit untuk memahami pelayanan yang diselenggarakan oleh birokrasi publik. Masyarakat sering dihadapkan pada begitu banyak ketidakpastian ketika mereka berhadapan dengan birokrasi. Amat sulit memperkirakan kapan pelayanan itu bisa diperolehnya. Begitu pula dengan harga pelayanan, baik harga ataupun waktu seringkali tidak bisa terjangkau oleh masyarakat sehingga banyak orang yang kemudian enggan berurusan dengan birokrasi publik.

Disamping itu rutinitas tugas-tugas pelayanan dan pelayanan yang berlebihan pada pertanggungjawaban formal (formal accountability) telah mengakibatkan prosedur kerja yang kaku dan lamban serta kurang responsif. "Formalistik merupakan salah satu ciri birokrasi di negara berkembang, yang mana semakin formalistik situasi administrasi, maka semakin kurang pengaruhnya terhadap perilaku yang sesuai dengan norma-norma yang digariskan" Riggs (1996:19). Dengan demikian memperhatikan kinerja dan kualitas pelayanan pemerintahan yang masih memprihatinkan dapat dilihat dari biaya yang banyak dalam pengurusan .

Kinerja aparat pada Sekretariat Daerah Kabupaten Muna dalam memberikan pelayanan publik sering kali masih menerapkan standar nilai atau norma pelayanan secara sepihak, seperti pemberian pelayanan yang hanya berdasarkan pada juklak (petunjuk pelaksanaan) sehingga kecenderungan yang terjadi adalah lemahnya komitmen aparat birokrasi untuk akuntabel terhadap masyarakat yang dilayani.

Secara empirik bahwa identifikasi masalah yang dapat dikemukakan dalam penelitian ini adalah sebagai berikut : (l) Belum adanya kebijakan yang memberikan pelayanan gratis kepada publik, yang ditandai dengan kurangnya keinginan masyarakat untuk berurusan pada Sekretariat Daerah Kabupaten Muna, (2) Para pegawai sebagai pelayan publik yang menunjukkan minimnya kesungguhan dalam memberikan pelayanan optimal, hal tersebut terlihat bahwa disiplin pegawai yang relatif kurang, pada bulan Agustus 2017, jumlah yang absensi ada 15 persen yang tidak hadir, sedangkan pada bulan September 17 persen yang tidak hadir, (3), Minimnya sumber daya dan rendahnya kualitas sumber daya manusia dalam memberikan pelayanan publik, hal tersebut mengakibatkan tidak optimalnya kualitas pelayanan publik yang dilaksanakan pada pada Sekretariat Daerah Kabupaten Muna, (4) Bahwa dalam penempatan pegawai banyak menimbulkan ketidak puasan, karena penempatan tidak sesuai dengan bidang keahlian pegawai dan belum adanya acuan yang baku dan objektif yang dapat diterima oleh semua pihak, (Hasil wawancara, 2017), (5) Masih adanya perasaan yang tidak nyaman terhadap para pegawai dalam melaksanakan tugas dan tanggung jawab, karena tidak adanya motivasi kerja yang dilakukan oleh pimpinan. Sehingga pegawai banyak yang meninggalkan tugas pada jam kerja tanpa ada alasan yang jelas. 
Vol.2 No.2. July 2019. pp.31-42. Copyright@2019 Journal PUBLICUHO Faculty of Social and Political Sciences Halu Oleo University, Kendari, Southeast Sulawesi, Indonesia. e-ISSN: 2621-1351.Open Access at:

http://ojs.uho.ac.id/index.php/PUBLICUHO

Jounal publiuho is licensed under a Creative Commons Attribution 4.0 International License, which permits unrestricted use, distribution, and reproduction in any medium, provided the original work is properly cited.

Berkaitan dengan hal tersebut, bila mencermati pelayanan aparat pemerintah pada pada Sekretariat Daerah Kabupaten Muna, menunjukkan masih terdapat penyimpangan aparatur birokrasi dan tingkah laku serta tindakan aparatur birokrasi sebagai pelayan masyarakat.

Fenomena tersebut menggambarkan kurang optimalnya kualitas pelayanan birokrasi dalam memberikan pelayanan yang selama ini dinikmati oleh masyarakat. Penelitian tentang masalah birokrasi dan kualitas pelayanan ini penting untuk dilakukan, dikarenakan masyarakat sebagai customer service belum merasa puas baik dari segi waktu, biaya dan mutu pelayanan yang selama ini diberikan. Untuk itu penelitian ini ditujukan untuk meneliti tentang Problem Birokrasi Dalam Meningkatan Pelayanan Publik Pada Sekretariat Daerah Kabupaten Muna.

\section{TINJAUAAN PUSTAKA}

\section{Konsep Birokrasi dan Realita Pelaksanaannya.}

Walaupun "birokrasi" adalah suatu kata yang lazim, namun pada hakekatnya sulit menangkap maknanya. Pernyataan ini berlaku khususnya pada saat kita merasa dikelilingi oleh birokrasi dan ketika kata sifat "birokratis" sama sekali bukanlah istilah terpuji. Weber memandang birokrasi sebagai bentuk organisasi dan administrasi, dimana kekuasaan pada organisasi secara keseluruhan berada di tangan para pejabat dengan keterampilan teknis adalah istilah penting disini, karena karakteristik birokrasi menunjukkan bahwa organisasi birokrasi pertama diorientasikan ke arah pemisahan keterampilan itu dari pengikisan pengaruh dari luar dan korupsi dari dalam organisasi itu dan kedua, mengelompokan dan membentuk spesialisasi keterampilan itu untuk kegunaan efisiensi.

Bagi Weber, badan birokratis modern (publik) atau birokratis usaha (swasta) beroperasi di dalam bidang juridiksi yang ditetapkan. Dengan demikian, birokrasi mengandung tiga unsur-unsur pokok :

1. Aktivitas reguler dari badan-badan pada organisasi ditetapkan sebagai "tugas-tugas resmi".

2. Tugas-tugas ini adalah relatif stabil dan otoritas untuk melaksanakan tugas-tugas secara ketat dibatasi dengan peraturan, karena otoritas/kewenangan memaksa tersedia untuk melaksanakan peraturan.

3. Terdapat cara-cara tetap dan reguler untuk menjamin keseimbangan ketetapan tugas-tugas ini oleh individu-individu yang memenuhi ketentuan umum atau kualifikasi tambahan.

Untuk memahami birokrasi, maka birokrasi konsepsi Weber merupakan konsep yang paling terkenal. Secara ekonomis kemampuan birokrasi Weber ini dapat digolongkan dalam pengertian bureau-rationality. Disini Weber mengajukan teori birokrasi dalam kerangka teorinya tentang dominasi, dimana Weber, menyebut hubungan kekuasaan melalui aparat legal-rational-domination sebagai birokrasi. (Mouzlies, 1973 : 39). Weber yakin bahwa:

Birokrasi rasional pasti bertambah penting dalam masyarakat modern. Hal ini disebabkan birokrasi memiliki serangkaian ciri-ciri: kecermatan, kontinuitas, disiplin, ketat, dapat diandalkan, yang membuat bentuk organisasi birokrasi paling memuaskan dari segi teknis.

Dengan demikian, baik pemegang otoritas maupun bagi semua pihak yang terlibat dalam organisasi. Disini Weber menyatakan bahwa birokrasi merupakan proses yang tidak terelakan. Tetapi sebagai bagian dari proses kearah rasionalisasi, maka birokrasi cenderung memprakarsai pada pemisahan orang-orang dari saranasarana produksi, dan pertumbuhan umum kearah formalisasi

Betapapun baik dan efisiennya suatu birokrasi, selalu mengandung di dalamnya ciri dan keterbatasan yang tidak selalu cocok untuk melaksanakan tugas-tugas pembangunan. Menurut Hadad (1983 : 8) ini disebabkan:

Birokrasi telah mempunyai pola kerja yang sudah mapan, dan langkah-langkah tindakannya harus selalu mengikuti kebijakan umum atau menunggu petunjuk-petunjuk dari atasan, serta dilakukan melalui jalur formal 
dan hirarki yang cukup panjang, keadaan ini membuat aparat birokrasi tidak punya peluang yang cukup untuk mengambil kepekaan atau bertindak dengan cepat, kurang punya fleksibilitas untuk menyesuaikan kebijakan dengan kondisi setempat, dan kurang kepekaan mengendalikan masalah-masalah khusus dan kebutuhan khas kelompok masyarakat daerah yang sering muncul silih berganti.

\section{Kualitas Pelayanan Publik}

Kualitas pelayanan dari birokrasi sangat berkaitan dengan kemampuan organisasi menyesuaikan dengan keinginan dan kebutuhan masyarakat sebagai pelanggan. Harper W. Jr, \& Walker Orville C. Jr (1992: 75) menyebutkan kepuasan pelanggan akan terwujud apabila organisasi mampu melaksanakan pelayanan dengan cara menciptakan "nilai pelanggan" (Marketing Management-A Strategic Approach).

Kemudian untuk melihat kualitas pelayanan tersebut, menurut Fitzstmmons (1994: 190) mengatakan dapat dilihat dari lima dimensi yaitu:

1. Reliability, kemampuan untuk memberikan secara tepat dan benar, jenis pelayanan yang telah dijanjikan kepada konsumen;

2. Responsiveness, kesadaran atau keinginan untuk membantu konsumen dan memberikan pelayanan yang cepat;

3. Assurance, pengetahuan atau wawasan, kesopansantunan, kepercayaan diri dari pemberi layanan, serta respek terhadap konsumen;

4. Empathy, kemauan pemberi layanan untuk melakukan pendekatan. memberi perlindungan serta berusaha untuk mengetahui keinginan dan kebutuhan konsumen;

5. Tangibles, penampilan para pegawai dan fasilitas fisik lainnya, seperti peralatan atau perlengkapan yang menunjang pelayanan.

Dari uraian tersebut, maka yang menjadi dasar dari kualitas pelayanan pada masyarakat (publik) adalah bahwa sistem kualitas memiliki ciri dan karakteristik tertentu. Pengertian efektivitas seperti ini merupakan rumusan yang sederhana yang sifatnya umum, karena bagi organisasi publik efektivitas tidak saja menggambarkan keberhasilan pencapaian sasaran sebagaimana yang ditetapkan, akan tetapi lebih dari itu pencapaian sasaran harus tetap mengacu pada nilai pemerataan, kemerdekaan keadilan sosial, partisipasi dan sebagainya.

Salah satu fenomena yang terjadi bahwa pelayanan publik yang diberikan pegawai masih kurang efektif dan kurang efisien, dimana penerbitan surat-surat berjalan lambat (tidak sesuai dengan ketentuan yang ditetapkan) ini berhubungan dan dipengaruhi oleh disiplin kerja sehingga pelaksanaan pelayanan publik menjadi lambat.

Kemudian fenomena yang lain yaitu pelayanan yang diberikan masih kurang menyenangkan dimana masih terdapat keluhan masyarakat yang mengatakan bahwa petugas terkesan angkuh dan sombong dalam memberikan pelayanan, sehingga masyarakat merasa kurang nyaman dalam berurusan, ini disebabkan karena indikator-indikator tersebut belum terlaksana dengan baik, dan ini disebabkan karena pegawai ataupun motivasi kerja belum memperhatikan secara optimal faktor ketelitian, kesesuaian, penilaian, kejujuran, kepatuhan, keyakinan, tata krama, tingkah laku, tutur kata, kemarahan (emosi), akibat, pemberian konfirmasi dan pemberian bantuan serta pemberian solusi sehingga mengakibatkan pelaksanaan pelayanan publik belum maksimal terlaksana. Secara eksplisit dapat dikatakan bahwa pemberian layanan publik merupakan jenis pelayanan yang dimonopoli oleh pemerintah. Hal ini dapat dipahami mengingat pelayanan publik merupakan bagian dari fungsi pemerintah yang memberikan pelayanan kepada masyarakat.

Layanan publik berkaitan dengan kegiatan-kegiatan yang dilakukan pemerintah untuk memenuhi kebutuhan masyarakat secara baik dan berkualitas sebagai konsekuensi dari tugas dan fungsi layanan yang diembannya, 
Vol.2 No.2. July 2019. pp.31-42. Copyright@2019 Journal PUBLICUHO Faculty of Social and Political Sciences Halu Oleo University, Kendari, Southeast Sulawesi, Indonesia. e-ISSN: 2621-1351.Open Access at:

http://ojs.uho.ac.id/index.php/PUBLICUHO

Jounal publiuho is licensed under a Creative Commons Attribution 4.0 International License, which permits unrestricted use, distribution, and reproduction in any medium, provided the original work is properly cited.

berdasarkan hak-hak yang dimiliki oleh masyarakat dalam rangka mencapai tujuan pemerintahan dan pembangunan.

Menurut Zeithmal dalam (Tjiptono 2002: 58) mengemukakan tentang pentingnya kualitas pelayanan bahwa:

Kualitas pelayanan adalah service excellence atau pelayanan yang unggul, yakni suatu sikap atau cara karyawan dalam melayani pelanggan secara memuaskan. Secara garis besar ada 4 (empat) unsur pokok dalam konsep pelayanan yang unggul, yaitu (1) Kecepatan; (2) Ketepatan; (3) Keramahan; (4) Kenyamanan. Keempat komponen ini merupakan suatu kesatuan pelayanan yang terintegrasi, maksudnya pelayanan atau jasa menajdi tidak excellence bila ada komponen yang kurang .

Dengan demikian kualitas pelayanan diibaratkan dengan memberikan pelayanan yang unggul dalam kecepatan, ketepatan, keramahan, dan kenyamanan, pelanggan akan merasa puas.

Ndraha (1997: 59) memberikan tekanan terhadap kualitas layanan, sebagai berikut: Jasa layanan atau layanan publik dipandang sebagai deviden yang wajib didistribusikan kepada rakyat oleh pemerintah dengan semakin baik, semakin tepat waktu, semakin mudah diperoleh dan semakin adil. Tekanan pada aspek-aspek kecepatan, ketepatan, kemudahan dan keadilan daiam layanan publik (publik) tersebut berkaitan dengan sifat sifat monopoli dari layanan publik (publik) dimana masyarakat tidak memiliki pilihan untuk mengharapkan layanan yang sama pada institusi lain diluar pemerintah.

Menurut Sutopo (2000: 30), terdapat dua istilah untuk pengertian ini, yaitu melayani dan pelayanan. Pengertian melayani adalah "membantu menyiapkan (mengurus) apa yang diperlukan seseorang" Sedangkan pelayanan adalah "usaha melayani kebutuhan orang lain". Dari dua pengertian itu dapat disimpulakan bahwa pelayanan adalah suatu usaha untuk membantu (mengurus) apa yang diperlukan orang lain, dengan demikian bahwa dari bantuan tersebut tidak diharapkan adanya imbalan jasa yang diberikan oleh sipemberi layanan, karena sifatnya hanya memberikan pelayanan semata.

Dengan demikian bahwa kualitas pelayanan publik adalah segala kegiatan pelayanan yang dilaksanakan oleh penyelenggaraan pelayanan publik sebagai upaya pemenuhan kebutuhan penerima pelayanan maupun pelaksanaan ketentuan peraturan perundang-undangan.

Secara keseluruhan, rangkaian untuk mengetahui Fungsi Birokrasi Dalam Meningktakan Pelayanan Publik pada Sekretarian Daerah Kabupaten Muna dapt di jelaskan dalam kerangka pikir pada gambar 1.

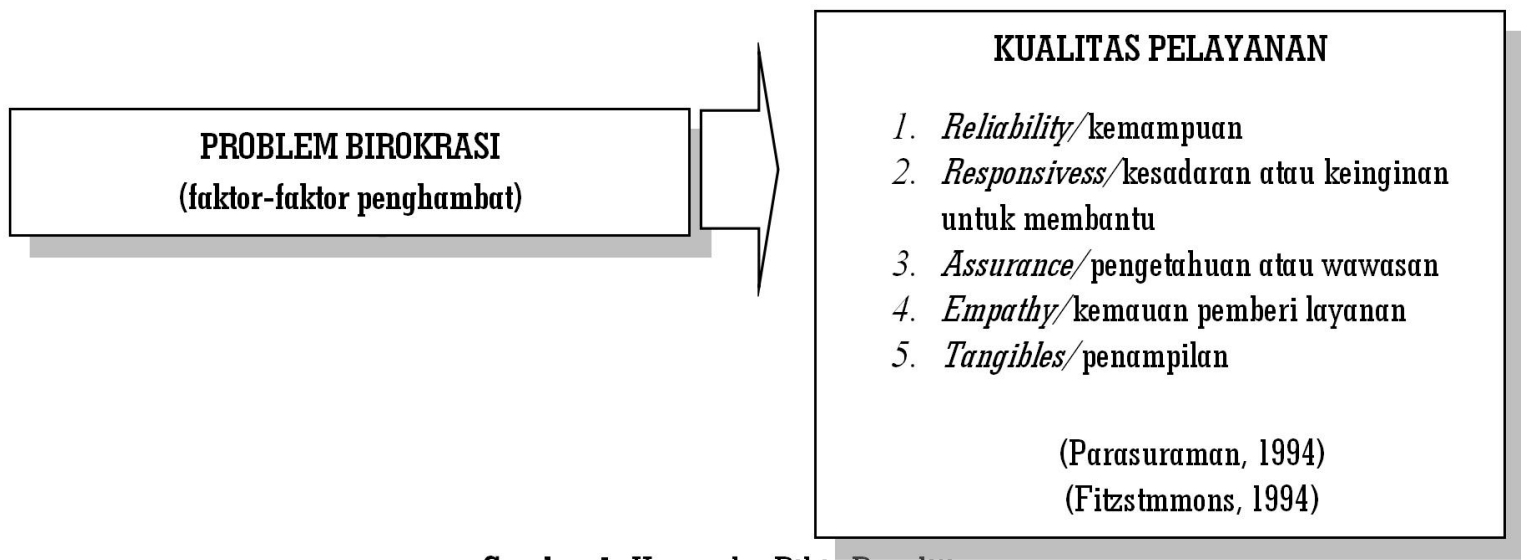

Gambar 1. Kerangka Pikir Penelitïan 


\section{METODE PENELITIAN}

Berdasarkan latar belakang masalah dan tujuan penelitian, maka metode penelitian ini adalah menggunakan jenis penelitian kualitatif dengan metode analisis deskriptif. Strategi pendekatan atau jenis penelitian kualitatif yang dipergunakan dalam penelitian ini adalah pendekatan naturalistic, yaitu bahwa: 1) Penelitian dapat dilaksanakan dengan kondisi alamiahnya; 2) Data yang dikumpulkan adalah berdasarkan perspektif yang diteliti; 3) Desain penelitiannya bersifat fleksibel karena berdasarkan prinsip reflexive; 4) Tidak ada standar dalam hal alat, metode observasi, maupun cara menganalisis.

Metode penelitian kualitatif sebagai prosedur penelitian yang menghasilkan data deskriptif berupa kata tertulis atau lisan dari orang-orang dan perilaku yang dapat diamati. Penelitian kualitatif lebih menghendaki arah bimbingan penyusunan teori substantif yang berdasarkan data. Melalui proses ini diharapkan muncul proposisi hipotetik baru melalui interpretasi interaksi antara atribut dan propretise yang selanjutnya digunakan untuk membangun kategori dan memberikan eksplanasi terhadap fenomena yang diteliti.

Kemudian informan dalam penelitian ini adalah informan yang dianggap dapat memberikan informasi tentang Pegawai Negeri Sipil khususnya birokrasi dalam pelayanan publik di Sekretariat Daerah Kabupaten Muna. Informan yang dipilih yaitu, Sekretaris Daerah Kabupaten Muna, Kepala Bagian Kepegawaian, Kepala bagian Umum, dan 2 orang staf pada Sekretariat Daerah Kabupaten Muna, serta 2 orang masyarakat yang pernah dilayani dalam satu tahun terakhir (2017).

\section{Teknik Pengumpulan Data}

Tehnik pengumpulan data dalam penelitian ini yaitu dengan menggunakan dua cara yakni ; (l) wawancara mendalam dan (2) studi dokumen.

\section{Teknik Analisis Data}

Analisis akan dilaksanakan secara terus menerus sejak awal penelitian hingga akhir penelitian. Model analisis data yang telah peneliti uraikan tersebut dapat digambarkan seperti terdapat pada gambar 2 .

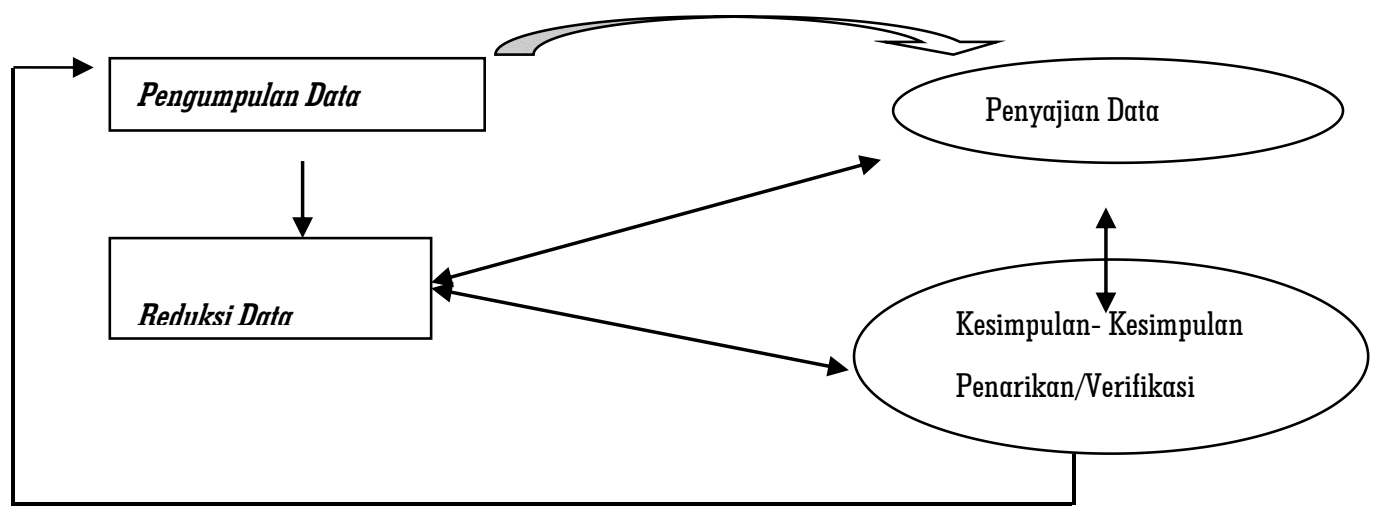

Gambar 2. Teknis Analisa Data

Sumber : Mattew B. Miles dan Michael Huberman, Analisis Data Kualitatif 


\section{PEMBĀHĀSAN}

Faktor-faktor yang menghambat birokrasi dalam rangka peningkatan Kualitas Pelayanan Publik Pada Sekretariat Daerah Kabupaten Muna

\section{Kemampuan Sumber daya manusia.}

Hasil penelitian menunjukkan bahwa perilaku pegawai merupakan salah satu perwujudan dari fungsi aparatur sebagai abdi negara dan abdi masyarakat untuk mensejahterakan masyarakat. Pemberian pelayanan yang menekankan pada kepuasan terhadap yang dilayani, yaitu bagaimana birokrasi pada Sekretariat Daerah Kabupaten Muna menyampaikan pelayanan kepada masyarakat. Ketetapan strategi pemberian pelayanan pemerintah daerah ditentukan oleh kualitas pelayanan yang ditawarkan dan diukur oleh pelayanan fasilitas fisik yang dinikmati dan dirasakan oleh masyarakat saat berurusan pada Pada Sekretariat Daerah Kabupaten Muna.

Kelemahan sumber daya manusia dalam peningkatan kualitas pelayanan pada Sekretariat Daerah Kabupaten Muna, melalui penelitian ini ditemukan bahwa kelemahan sumber daya manusia pelaksana pelayanan relatif terbatas, sehingga dalam proses pelayanan sering mengalami keterlambatan, misalnya proses surat menyurat yang berhubungan dengan penulisan melalui komputer terkadang mengalami keterlambatan yang karena operator berhalangan atau terlambat masuk kantor, sehingga pelaksanaannya tidak tepat waktu.

Betapapun jelas dan konsistennya perintah dalam melaksanakan pelayanan dan akuratnya perintah tersebut disampaikan, namun apabila orang-orang yang bertanggung jawab terhadap pelayanan tersebut kekurangan sumber daya dalam memahami pekerjaan mereka, maka kebijakan tidak akan efektif. Sumber daya yang penting antara lain : jumlah staf yang cukup dengan keahlian yang memadai, informasi yang cukup dan relevan mengenai instruksi kebijakan, otoritas yang menjamin bahwa kebijakan tersebut dilaksanakan sesuai dengan apa yang dimaksud, dan fasilitas, termasuk bangunan-bangunan, fasilitas kantor dan fasilitas pendukung untuk memberikan pelayanan.

\section{Penggunaan/pemakaian Sarana dan Prasarana Pelayanan}

Faktor yang perlu diperhatikan dalam pelayanan publik adalah tersedianya sarana dan prasarana pendukung yang mencakup antara lain fasilitas gedung kantor dan perlengkapannya, sarana komunikasi. Ini berarti bahwa fasilitas sarana dan prasarana fisik, harus dapat diandalkan karena dianggap sebagai bukti nyata dari pelayanan yang diberikan kepada masyarakat.

Fasilitas pendukung yang dimiliki pada Sekretariat Daerah Kabupaten Muna telah memenuhi kebutuhan pelayanan, namun pemanfaatannya yang relatif belum optimal, hal ini dimungkinkan karena keterbatasan sumber daya manusia yang belum dapat memanfaatkan fasilitas tersebut, karena belum semua pegawai dapat mengoperasikan komputer secara optimal.

Kantor merupakan sarana utama tempat melakukan berbagai kegiatan pelayanan, karena itu kantor haruslah memenuhi standar sebagai tempat untuk melaksanakan tugas-tugas administrasi pelayanan. Sekretariat Daerah Kabupaten Muna memiliki sebuah kantor yang mudah dijangkau masyarakat karena dilewati jalan lingkar perkantoran bupati Muna. Selain kantor yang tersedia juga dilengkapi dengan berbagai fasilitas seperti telepon, komputer personal (PC), laptop, mesin ketik,TV, dan meja, kursi tempat duduk, tempat sampah, asbak rokok. Tersedianya fasilitas sarana dan prasarana yang digunakan dalam pelayanan merupakan faktor pendukung kelancaran pelayanan yang dilakukan secara cepat, nyaman, dan berkualitas. 
Vol.2 No.2. July 2019. pp.31-42. Copyright@2019 Journal PUBLICUHO Faculty of Social and Political Sciences Halu Oleo University, Kendari, Southeast Sulawesi, Indonesia. e-ISSN: 2621-1351. Open Access at:

http://ojs.uho.ac.id/index.php/PUBLICUHO

(C)
unrestricted use, distribution, and reproduction in any medium, provided the original work is properly cited.
undition

Birokrasi dalam memberikan pelayanan menawarkan semua yang tersebut dengan kemungkinan optimum yang dilaksanakan melalui prinsip spesialisasi fungsi-fungsi administratif sosial dengan pertimbanganpertimbangan objektif semata. Prestasi individu dialokasi pada fungsionaris yang memperoleh pelatihan spesialis dan yang secara terus menerus meningkatkan keahliannya. Pengeluaran bisnis "objektif" terutama cara-cara pengeluaran bisnis sesuai dengan ketentuan yang dapat dihitung dan tanpa tergantung pada perorangan.

Sesuai wawancara dengan Kepala bagian umum Kabupaten Muna bahwa, pegawai pada Sekretariat Kabupaten Muna sudah memberikan pelayanan sebagaimana ketentuan dan kebutuhan setiap bagian, walaupun disadari bahwa keterbatasan sumber daya manusia yang sesuai bidang pekerjaan dan latar belakang keahlian terkadang bertolak belakang, sehingga mengurangi kualitas pelayanan.

Menurut pendapat Tjiptoherijanto dan Yumiko (1983 : 45) menyatakan bahwa pengaruh kapabilitas birokrasi dalam memberikan pelayanan terhadap kehidupan manusia telah menembus hingga ke dalam masyarakat pedesaan. Di pedesaan misalnya, pengaruh birokrasi dalam memberikan pelayanan atas desa telah mulai nampak sejak zaman kolonial secara lebih mencolok terlihat mulai tahun 1960. Keterlibatan birokrasi dalam memberikan pelayanan ini nampak jelas dengan semakin banyaknya program pembangunan dilaksanakan di daerah pedesaan.

Untuk memahami problem birokrasi dalam memberikan pelayanan pada Sekretariat Daerah Kabupaten Muna, maka birokrasi konsepsi Weber merupakan konsep yang paling terkenal. Secara ekonomis kemampuan birokrasi Weber ini dapat digolongkan dalam pengertian bureau-rationality. Disini Weber mengajukan teori birokrasi dalam kerangka teorinya tentang dominasi, dimana Weber, menyebut hubungan kekuasaan melalui aparat legal-rational-domination sebagai birokrasi (Mouzlies, 1973 : 39). Weber yakin bahwa birokrasi rasional pasti bertambah penting dalam masyarakat modern. Hal ini disebabkan birokrasi memiliki serangkaian ciri-ciri: kecermatan, kontinuitas, disiplin, ketat, dapat diandalkan, yang membuat bentuk organisasi birokrasi paling memuaskan dari segi teknis. Baik pemegang otoritas maupun bagi semua pihak yang terlibat dalam organisasi. Disini Weber menyatakan bahwa birokrasi merupakan proses yang tidak terelakan. Tetapi sebagai bagian dari proses kearah rasionalisasi, maka birokrasi cenderung memprakarsai pada pemisahan orang-orang dari sarana-sarana produksi, dan pertumbuhan umum kearah formalisasi dalam organisasi.

Sesuai hasil wawancara dengan staf pada sekretariat Daerah Kabupaten Muna bahwa, setiap pegawal sudah ada tugas pokok dan fungsinya (Tupoksi) yang harus dilaksanakan setiap han sehingga, setiap pegawai tidak ada lagi yang kurang jelas tugasnya karena telah dibagi sesuai bagian atau tempat dimana pegawai tersebut ditempatkan, walaupun masih ada pegawai yang terkadang diperbantukan ditempat lain kalau ada pekerjaan mendesak, namun sifatnya hanya sementara, sehingga pegawai seharusnya sudah mengetahui pekerjaannya dalam memberikan pelayanan, walaupun masih ada pegawai yang belum sepenuhnya

dapat melaksanakan tugasnya dengan baik, dan pada umumnya pegawai tersebut masih baru dibidangnya sehingga masih memerlukan pembinaan dalam menyelesaikan pekerjaannya.

Berdasarkan pembahasan sebelumnya nampak bahwa meskipun kapabilitas birokrasi dalam memberikan pelayanan merupakan bentuk-bentuk organisasi yang paling ideal untuk menyalurkan program-program pembangunan, namun dalam prakteknya sifat birokratik yang melekat di dalamnya justru menghambat tugastugas pembangunan yang seharusnya di lakukan organisasi birokratik cenderung untuk memilih klien yang dianggap lebih menguntungkan dan memudahkan tercapainya sasaran organisasi.

Sesuai hasil penelitian bahwa keberadaan birokrasi khususnya Sekretariat Daerah Kabupaten Muna, bertujuan memperlancar daripada pelayanan, namun dalam pelaksanaannya belum sesuai yang diharapkan, menurut penulis bahwa kenerja birokrasi dapat berjalan secara efektif dan sesuai yang diharapkan apabila semua unsur- 
Vol.2 No.2. July 2019. pp.31-42. Copyright@2019 Journal PUBLICUHO Faculty of Social and Political Sciences Halu Oleo University, Kendari, Southeast Sulawesi, Indonesia. e-ISSN: 2621-1351.Open Access at:

http://ojs.uho.ac.id/index.php/PUBLICUHO

(C) Jounal publiuho is licensed under a Creative Commons Attribution 4.0 International License, which permits
unrestricted use, distribution, and reproduction in any medium, provided the original work is properly cited.

unsur yang termasuk dalam struktur organisasi memperhatikan fungsi-fungsi birokrasi dapat berjalan sebagaimana mestinya.

Dengan demikian bahwa untuk memberikan pelayanan yang optimal maka perlu peningkatan kemampuan sumber daya manusia dalam hal ini adalah pegawai berupa pendidikan dan pelatihan merupakan pemberian bekal bagi sumber daya manusia untuk meningkatkan kapabilitasnya dalam melakukan pelayanan publik. Hal tersebut sejalan yang dikemukakan oleh Flippo (1989 : 215), bahwa pendidikan dan pelatihan memegang peranan kunci bagi organisasi untuk mempersiapkan dan mengembangkan pegawainya dalam upaya meningkatkan kapabilitasnya, baik pada saat rekrutmen, seleksi, maupun setelah bekerja. Pendapat Flippo tersebut sebagai berikut : Sesudah karyawan direkrut (ditarik), dipilih, dan dilantik atau diperkenalkan, selanjutaya dia harus dikembangkan agar lebih sesuai dengan pekerjaan dan organisasi. "Tidak seorangpun yang sepenuhnya sesuai pada saat pengangkatan, sehingga harus dilakukan pendidikan dan pelatihan. Tidak ada pilihan lain, perusahaan harus mengembangkan para karyawannya: pilihan satu-satunya adalah tentang metodenya. Jika tidak ada program yang terorganisasi, sebagian besar pelatihan akan merupakan pelatihan diri sendiri sambil belajar dalam pekerjaan. Pelatihan meliputi baik pelatihan untuk meningkatkan pengalamandalam melaksanakan pekerjaan tertentu maupun pendidikan untuk meningkatkan pelatihan umum dan pemahaman atas keseluruhan lingkungan kerja.

Birokrasi dalam memberikan pelayanan public perlu mempersiapkan sumber daya yang baik, dengan melaksanakan Pendidikan dan Pelatihan kepada pegawai, walaupun diperlukan waktu dan dana yang tidak sedikit tetapi hasil yang akan diperoleh jauh lebih besar, menurut Nitisemito (1996 : 54) yaitu "pekerjaan akan dilakukan lebih cepat dan lebih baik, kerusakan dapat diperkecil, pemborosan dapat ditekan, peralatan dapat digunakan secara lebih baik dan kecelakaan dapat diperkecil". Hal ini sesuai dengan pendapat Wursanto (1989 : 6l) tentang tujuan diadakannya Pendidikan dan Pelatihan yaitu : (1) Menambah pelatihan ; (2) Menambah pengalaman pegawai; (3) Mengubah dan membentuk sikap pegawai; (4) Mengembangkan keahlian pegawai sehingga pekerjaan dapat diselesaikan dengan lebih cepat dan efektif; (5) Mengembangkan semangat, kemauan dan kesenangan kerja pegawai; (6) Mempermudah pengawasan terhadap pegawai; (7) Mempertinggi stabilitas pegawai.

Sesuai hasil wawancara dengan, Kepala Bagaian Kepagawaian Kabupaten Muna, bahwa,

"Setiap penempatan pegawai yang ada pada Kantor Sekretariat Daerah Kabupaten Muna saya selalu berupaya menyesuaikan antara latar belakang pendidikan dan bidang pekerjaan yang tersedia, namun karena ketersediaan sumber daya manusia relatif belum memadai sehingga ada pegawai yang ditempatkan tidak sesuai dengan latar belakang pendidikannya, sehingga pegawai mampu menyesuaikan dengan tugas pokok yang akan dilaksanakan."

Dengan demikian menurut Hersey dan Blanchard, (1982:15) bahwa pembentukan kapabilitas birokrasi pada dasarnya merupakan rangkaian aktifitas yang berorientasi kepada tujuan-tujuan tertentu. Dengan begitu kapabilitas birokrasi dapat dinyatakan sebagai bentuk reaksi yang nyata berupa tindakan seseorang yang arahnya sesuai dengan dorongan yang tumbuh dari dalam diri seseorang, yang tentunya akan baik apabila didasari oleh pendidikan yang memadai.

Kapabilitas birokrasi dapat dilaksanakan dengan optimal apabila didukung oleh tingkat pendidikan dan pelatihan pegawai yang baik, karena pelaksanaan pendidikan dan pelatihan juga bertujuan untuk memberikan kesempatan pada para pegawai dalam peningkatan kecakapan dan ketrampilannya terutama dalam bidang bidang yang berhubungan dengan pelayanan, pengawasan dan teknis yang sangat diperlukan dalam mencapai tujuan suatu organisasi, kemudian pembinaan pegawai harus sesuai dengan kebutuhan jabatan dalam organisasi, sikap atau pengalaman yang akan dicapai dengan pemberian pengetahuan yang bersangkutan.

Proses penyelarasan semua kegiatan yang di arahkan untuk menunjang pencapaian tujuan merupakan suatu hal penting bagi suatu organisasi. Kegiatan demikian mau tidak mau harus dilaksanakan bila menginginkan 
Vol.2 No.2. July 2019. pp.31-42. Copyright@2019 Journal PUBLICUHO Faculty of Social and Political Sciences Halu Oleo University, Kendari, Southeast Sulawesi, Indonesia. e-ISSN: 2621-1351. Open Access at:

http://ojs.uho.ac.id/index.php/PUBLICUHO

Jounal publiuho is licensed under a Creative Commons Attribution 4.0 International License, which permits unrestricted use, distribution, and reproduction in any medium, provided the original work is properly cited.

kegiatan-kegiatan dalam organisasi berjalan lancar. Tanpa adanya kapabilitas organisasi maka organisasi tidak akan mengharapkan pegawai mempunyai prestasi yang baik, dan setiap orang akan kehilangan pedoman kerja tentang peranan apa yang harus dilaksanakan dalam organisasinya.

Kemudian kuantitas kerja dalam pelaksanaan pelayanan tergantung pada keberhasilan suatu birokrasi menetapkan jam kerja dan memadukan satuan-satuan/unit-unit kerja yang bermacam-macam kedalam suatu unit pelayanan. Kapabilitas pegawai dalam menjalankan pelayanan terhadap masyarakat secara akurat dan terpercaya menjadi salah satu ukuran keberhasilan pegawai dalam melaksanakan programnya. Kuantitas kerja dalam memberikan pelayanan merupakan suatu kesatuan yang dapat meningkatkan produktivitas suatu organisasi, sehingga dapat menimbulkan semangat kerja baik antar unit terkait maupun antar lembaga terkait, dengan demikian harapan untuk memberikan pelayanan yang baik dalam melancarkan arus pekerjaan dapat terwujud.

Berdasarkan wawancara dengan informan, menjelaskan bahwa, suasana formalitas kami senantiasa tegakkan, agar pelayanan yang diberikan terhindar dan praktek-praktek percaloan, nepotisme, kolusi, atau sogok. Dalam menerapkan kewenangan, maka setiap instansi membuat aturan yang sesuai dengan

Kepentingan dalam memberikan pelayanan,sehingga dapat meningkatkan kualitas pelayanan.

Dengan demikian sesuai pendapat Oentoro (2004:170) sedikitnya ada tiga fungsi utama yang harus dijalankan oleh pemerintah tanpa memandang tingkatannya, yaitu fungsi pelayan masyarakat, fungsi pembangunan dan fungsi perlindungan. Ketiga fungsi tersebut merupakan satu kesatuan yang harus dijalankan dalam waktu bersamaan sebagaimana tujuan keberadaan pemerintah. Kemudian adalah sejauh mana pemerintah dapat mengelola fungsi-fungsi tersebut agar dapat menghasilkan barang dan jasa (pelayanan) yang ekonomis, efektif, efisien dan akuntabel kepada seluruh masyarakat yang membutuhkannya.

Meskipun pemerintah mempunyai fungsi-fungsi sebagaimana tersebut, namun tidak berarti bahwa pemerintah harus berperan sebagai monopolist dalam pelaksanaan seluruh fungsi-fungsi tadi. Beberapa bagian dari fungsi tadi bisa menjadi bidang tugas yang pelaksanaannya dapat dilimpahkan kepada pihak swasta ataupun dengan menggunakan pola kemitraan (partnership), antara pemerintah dengan swasta untuk mengadakannya. Pola kerjasama antara pemerintah dengan swasta dalam memberikan berbagai pelayanan kepada masyarakat tersebut sejalan dengan gagasan reinventing government yang dikembangkan Osborne dan Gaebler (1992).

Berdasarkan wawancara dengan staf Sekretariat Daerah Kabupaten Muna, bahwa, dalam menjalankan tugastugas, setiap han sudah ada wewenang setiap pegawai yang harus diselesaikan, sehingga tidak lagi menunggu perintah dariatasan untuk melaksanakan tugas-tugas tersebut, kecuali ada tugas yang sifatnya mendesak untuk diselesaikan, maka terkadang pegawai harus lembur untuk menyelesaikan tugas tersebut, namun masih ada pegawai yang belum sepenuhnya memperhatikan tugas-tugas yang dibebabankan kepadanya tersebut.

Peningkatan kinerja birokrasi dalam memberikan pelayanan dimaksudkan agar masyarakat yang dilayani merasa puas atas apa yang diinginkan, hal tersebut sesuai pendapat Kotler (1997 : 36) dan Tjiptono (1997 : 24) sama-sama mendefinisikan kepuasan masyarakat sebagai perasaan senang atau kecewa yang berasal dari perbandingan antara kesannya terhadap kinerja (atau hasil) suatu produk dan harapan-harapannya. Definisi kepuasan tersebut mencerminkan bahwa kepuasan masyarakat merupakan fungsi dari kesan kinerja (performance) dan harapan yang diinginkan konsumen (important). Jika performance memenuhi harapan, maka pelanggan akan puas. Jika kinerja melebihi harapan maka pelanggan akan sangat puas dan akan sangat senang.

Dengan demikian, dapat diketahui dan dipahami bahwa untuk mengukur kualitas pelayanan publik yang baik tidak cukup hanya menggunakan indikator tunggal, namun harus menggunakan multi-indikator atau indikator ganda dalam pelaksanaannya. Karena itu dimensi-dimensi pelayanan yang disajikan tersebut, sangat 
Vol.2 No.2. July 2019. pp.31-42. Copyright@2019 Journal PUBLICUHO Faculty of Social and Political Sciences Halu Oleo University, Kendari, Southeast Sulawesi, Indonesia. e-ISSN: 2621-1351.Open Access at:

http://ojs.uho.ac.id/index.php/PUBLICUHO

Jounal publiuho is licensed under a Creative Commons Attribution 4.0 International License, which permits unrestricted use, distribution, and reproduction in any medium, provided the original work is properly cited.

berpengaruh kepada kualitas pelayanan yang diberikan oleh aparat, pada bidang pelayanan pemerintahan dan pembangunan; bidang ekonomi, bidang pendidikan, bidang kesehatan, bidang sosial, bidang kesejahteraan rakyat, dan bidang pertanahan dan sebagainya.

Perkembangan informasi yang sering menganggap bahwa barurusan pada kantor pemerintah dan harus menyiapkan dana yang banyak apabila ingin urusan cepat selesai berbelit-belit dan mempunyai birokrasi yang sangat panjang, dan inilah yang perlu diberikan pemahaman bahwa untuk berurusan di Kantor Sekretariat Daerah Kabupaten Muna hanya perlu menyiapkan berbagai syarat administrasi yang dibutuhkan agar pengurusan surat-surat lancar, sehingga anggapan yang sering terlontar pada masyarakat yang tidak mengetahui proses tersebut dapat memahami.

Berdasarkan hasil wawancara dengan, Kepala Bagian umum Sekreatariat Daerah Kabupaten Muna, bahwa, kualitas kerja pegawai Kantor Sekretariat Daerah Kabupaten Muna dalam pelayanan, selalu bersifat formal dan telah melaksanakan tugas-tugasnya sebagaimana yang telah ditentukan, namun belum

sepenuhnya melaksanakan tugasnya sesuai dengan target kerja yang telah ditentukan, hal tersebut disebabkan fasilitas yang tersedia relatif belum memadai dalam pelaksanakan pelayanan.

Salah satu bentuk organisasi yang sering digunakan oleh pemerintah dalam pelaksanaan program pelayanan adalah organisasi birokrasi. Menurut Kast and Rosenzweig (1990:5) ini disebabkan birokrasi pemerintah adalah satu-satunya organisasi yang memiliki lebih banyak kemampuan untuk melaksanakan pembangunan daripada organisasi kemasyarakatan lainnya. Berdasarkan hasil wawancara dengan, staf pada Sekreatariat Daerah Kabupaten Muna, bahwa, dalam menjalankan tugas-tugas yang diberikan pimpinan, kami selalu menjalankan sesuai dengan ketentuan yang ada, serta bersifat formal, yang bertujuan untuk menghindari terjadinya kesalahan dalam memberikan pelayanan, serta menghindari adanya kolusi, korupsi dan Nepotisme (KKN), jadi plmpman selalu mengingatkan agar selalu bekerja profesional, sesuai tugas yang dibebankan.

Menurut penulis bahwa ukuran akuntabilitas dan responsibilitas yang selama ini digunakan dalam pelayanan pada Kantor Sekretariat Daerah Kabupaten Muna harus diubah. Sebagai lembaga pelayanan cenderung memiliki perspektif yang sempit dalam menilai kinerja dan kepatuhan. Kinerja dinilai dan kepatuhan terhadap peraturan dan prosedur, sementara peraturan dan prosedur dipahami secara statis dan tekstual serta tidak memberikan ruang terhadap kontekstualisasi dan relevansi dan peraturan dan prosedur itu sendiri, dengan demikian pegawai hams diberikan kewenangan dan keleluasaan untuk berkreasi dalam memberikan pelayanan sehingga balk pegawal yang bertugas maupun yang dilayani merasa puas dalam menenima layanan.

Sesuai hasil penelitian tentang prolematika birokrasi dalam rangka meningkatkan kualitas pelayanan publik pada Sekretariat Daerah Kabupaten Muna penulis mengukur kualitas pelayanan digunakan teori menurut Fitzstmmons (1994:190) yaitu: (1) Reliability, kemampuan untuk memberikan secara tepat dan benar, jenis pelayanan yang telah dijanjikan kepada konsumen; (2) Responsiveness, kesadaran atau keinginan untuk membantu konsumen dan memberikan pelayanan yang cepat, (3) Assurance, pengetahuan atau wawasan, kesopansantunan, kepercayaan diri dari pemberi layanan, serta respek terhadap konsumen; (4) Empathy, kemauan pemberi layanan untuk melakukan pendekatan. memberi perlindungan serta berusaha untuk mengetahui keinginan dan kebutuhan konsumen; (5) Tangibles, penampilan para pegawai dan fasilitas fisik lainnya, seperti peralatan atau perlengkapan yang menunjang pelayanan. Dengan demikian bahwa teori tersebut mendukung dari pada penelitian ini. 


\section{KESIMPULAN}

Faktor-faktor yang menghambat birokrasi dalam rangka peningkatan Kualitas Pelayanan Publik Pada Sekretariat Daerah Kabupaten Muna yaitu, sumberdaya manusia yang yang melaksanakan tugas-tugas pelayanan belum optimal. Karena sebagian besar yang bertugas dalam pelayanan mempunyai latar belakang pendidikan SMA yaitu sebanyak 19 orang atau 31.67 persen. Kemudian Fasilitas pendukung yang dimiliki pada Sekretariat Daerah Kabupaten Muna telah memenuhi kebutuhan pelayanan, namun pemanfaatannya yang relatif belum optimal, hal ini terjadi karena keterbatasan sumber daya manusia dalam memanfaatkan fasilitas sumberdaya yang ada.

\section{DAFTAR PUSTAKA}

Fritzsimon, James A dan Mona J. Fritzsimon. 1994. Service Management for Competitive Advantage. Newyork: Mc. Graw. Hill International Edition.

Hadad., 1993. Pengantar Hukum Administrasi Indonesia. (Introduction Administrative Law). Yogyakrta; Gadjah Mada University Press.

Miles \& Huberman. 2000. Analisis Data Kualitatif. Jakarta: UI Press

Mouzlies, Nico P. 1973. Organizational and Bureucracy An Analisys of Modern Theories. Chicago: Aldine Publishing Company.

Nraha, Taladziluhu. 1997. "Persiapan Masyarakat Dalam Pembangunan" Rineka Cipta-Jakarta.

Osborne, D. dan Gebler. 1992. Mewirausahakan Birokrasi. (terjemahan Abdul Rosyid). Jakarta: Pustaka Binarnan Pressindo.

Parasuraman, Zeithaml Berry, 1998. Serv.Qual: A Multy-Item Scale foe Measuring Consumer Perseption Of Service Quality, Journal of retailing

Riggs, Fred W., 2006. The Prismatic Model: Conceptualizing Transitional Societies. Dalam, Comparative Public Administration: The Essential Readings. Research in Public Policy Analysis and Management, Volume 15. Edited by Eric E. Otenyo and Nancy S. Lind. Oxford: Elsevier Ltd., 17-60.

Sutopo. 2000. Pelayanan Prima. Lembaga Administrasi Negara.

Tjiptoherijanto dan Yumiko, 1983. Demokrasi dan Pedesaan Jawa, Sinar Harapan dan Lembaga Penerbitan FE UI; Jakarta.

Tjiptono, Fandy. 2002. Strategi Pemasaran . Cetakan Pertama, Offset . Yogyakarta. 